\title{
Language Politeness Among Adolescents: Sociolinguistic Study
}

\author{
Koni Hasa Enda Citra \\ Institut Agama Islam Negeri Bengkulu \\ konycantikri@gmail.com \\ Kasmantoni \\ Institut Agama Islam Negeri Bengkulu \\ Kasmantoni1975@gmail.com \\ Heny Friantary \\ Institut Agama Islam Negeri Bengkulu \\ Henyfriantary30@gmail.com
}

\begin{abstract}
The problem raised in this study is how to comply with the principles of politeness in language and is there a violation of the principles of politeness in language among teenagers in Telaga Dewa V RT 15 Bengkulu City in terms of communicating and interacting. The purpose of this study is to describe the adherence to the principles of language politeness and violations of the principles of language politeness among adolescents in Telaga Dewa V RT 15 Bengkulu City in terms of communicating and interacting. This type of research is descriptive qualitative research. The subject of this study is the act of politeness in language performed by teenagers in Telaga Dewa V, RT 15, Bengkulu City in the form of conversation or interaction. While the informants in this study were several teenagers who lived in Telaga Dewa V, RT 15, Bengkulu City. Data collection techniques in the form of observation, documentation and interviews. The results of this study conclude that there are four maxims that are obeyed by adolescents in Telaga Dewa V, RT 15, Bengkulu City, namely tact maxim, generosity maxim, approbation maxim and modesty maxim which consists of 23 utterances. There were four violations of the principle of politeness in language at Telaga Dewa V, RT 15, Bengkulu City, namely the maxim of wisdom, the maxim of generosity, the maxim of appreciation/praise and the maxim of simplicity/humility which consists of 11 utterances.
\end{abstract}

Keywords: Language Politeness, Adolescent, Sociolinguistic, Maxim.

\section{A. Introduction}

Humans are social being who cannot possibly live alone without the presence of other people to carry out the process of interaction or communication. This proves the need for an important component in an interaction so that an effective communication process or speech act can occur. By the component, it mrans language. Language is one of the medium used by humans in the process of interaction and communication as well as an intermediary in conveying information during the process of interaction in society. 
Traditionally it can be said that the function of language is a tool to interact or as a tool to communicate between humans with one another, in the sense that language is used to convey information, feelings and ideas, or a concept. (Abdul Chaer and Leonie Agustina 2004). This confirms the existence of politeness in language so that it can create a sense of friendliness for speakers towards speech acts. In using language, a speaker needs to pay attention to the situation and the conditions. This is done so that there is no dispute and offend the listener.

Language politeness is reflected in communication procedures through verbal signs or language procedures. Language procedures must be in accordance with the cultural elements that exist in the society in which they live and the use of a language in communication. For example, politeness in language is like a person who is said to be of high character, if he interacts using language that is smooth and also polite. On the other hand, if someone speaks harsh and disrespectful words, it can be said that it is rude. Therefore, language politeness in the community is very important in order to create a harmonious and comfortable environment.

Language politeness as a sociolinguistic study is based on the view of sociolinguists that sociolinguistics examines the relationship between language and society (Siti Fauziah, 2016). Thus language politeness is also a form of behavior in language used by the language community in order to create a polite language in communicating. Language politeness is also used to respect and appreciate one another in the process of interaction and communication (Chaer, 2010). For example of language politeness, as found in a family environment, where a child is more polite in speaking his language to older people.

Adolescence is an age where individuals experience development both physically and mentally, the age of adolescence starts from the age of 12 years to 21 years (Miftahul Jannah, 2016). Teenagers know which ones are good and which ones are bad, but some of them are found to have an impatient attitude and always think about their own views and rarely want to accept or listen to the opinions of others, as well as politeness in language (Rimbing, 2020). There are so many teenagers who pay less attention to ethics or the level of politeness in language. 
This could be due to several factors, both in terms of association or the place where the continuity of the language occurs as well as family environmental factors.

In terms of language, a teenager is one of the members of the community who is very closely related to acts of language politeness in carrying out actions or interactions, both with fellow teenagers or with people who are older than the speaker, in this case, teenagers. In addition, language also plays an important role in conveying a message between speakers and speech acts in order to create an effective and meaningful interaction. Language is a communication system between members of society in using sounds that work through human speech and hearing and using symbols of speech sounds that have arbitrary conventional meanings (Subyantoro, 2014).

Polite language should get special attention for speakers or language users in carrying out a communication to other people in social life. In addition, politeness in language should be cultivated in every individual in society so that they can pay attention to polite language speech and maintain attitudes in carrying out the process of speech acts in communicating, in this case especially among teenagers. Teenagers need to be educated and nurtured so that they can use polite language both with each other and with the wider community, especially with older people. This is intended so that teenagers are more likely to maintain polite grammar in social life and avoid arrogant and rude language expressions.

Based on the results of preliminary observations made by researchers at Telaga Dewa V, Neighborhood Unit 15 in Bengkulu City, Researchers found various problems regarding language politeness in Telaga Dewa V, Bengkulu City, especially among teenagers who of course have very diverse languages in speech. Based on the existing reality, some of the teenagers are said to have used language according to the rules that apply in society. One example is where there is the behavior of teenagers who have shown good and polite language attitudes such as respecting older people with a soft and polite language attitude when speaking. In addition, in the communication process in the community, there are also some teenagers who are said to be quite good in terms of polite language and avoid words that contain elements of violence or harsh words in speaking with others or 
with other communities in the environment around them. This is certainly a good sign for the progress of language in the youth environment at Telaga Dewa $\mathrm{V}$ Bengkulu City in a polite language process.

However, there are also many teenagers who have not been able to use the rules of language politely in communicating both with fellow teenagers and with other communities in the process of interaction and communication. There are so many teenagers who still use arrogant and rude language in social life and in daily communication processes. This often happens to some teenagers in Telaga Dewa V Bengkulu city in carrying out the interaction process in the family or community environment.

The main factors that influence the level of language politeness in adolescents in Telaga Dewa V RT 15 Bengkulu City are environmental factors and the social factors of teenagers themselves in carrying out speech acts. This can be seen from some teenagers who use language that is less polite and rude to each other or to their parents as a result of environmental influences or bad associations. To overcome this, efforts to create an environment for the generation of teenagers who speak politely are things that must be considered together both from the surrounding environment, the community and especially the family, in order to foster an active level of politeness, especially in language as a means of communication.

With this, researchers are interested in examining the use of distinctive language in social interactions that occur among adolescents in Telaga Dewa Bengkulu City with the title Language Politeness among Adolescents at Telaga Dewa V RT 15 Bengkulu City: Sociolinguistic Study. The use of a distinctive language in Telaga Dewa among adolescents under study deserves to be studied in terms of sociolinguistics. This sociolinguistic study of language will be useful by observing and examining the use of language in the field of politeness. Therefore, the researcher examined the language politeness among the youth of Telaga Dewa Bengkulu City.

\section{B. Method}


This research was a research that used a qualitative descriptive method. Methods Qualitative research is a research and understanding process based on a methodology that investigates a social phenomenon and human problem (Moleong, 2012). Qualitative research aims to understand the phenomenon of what is experienced by the research subject, holistically by means of description in the form of words and language in a special context that is natural and utilizes various natural methods. (Sugiyono, 2012).

The subject in this study was the act of language politeness carried out by teenagers at Telaga Dewa V RT 15 Bengkulu City, which was studied through direct observation at the location. While the informants in this study were several teenagers who were examined for their language politeness in the communication process in society.

Data collection techniques used by researchers in collecting data in this study were through observation, documentation and interviews. The researcher used source (data) triangulation technique and method triangulation to test the validity of the data related to the research problem studied by the researcher. The data used in this study was the recording of interactions between adolescents in Telaga Dewa V RT 15 Bengkulu City. Furthermore, the data analysis technique used by the researcher was using a qualitative descriptive analysis technique consisting of identification, classification, description and analysis.

\section{Result and Discussion}

\section{Result}

The results of the research on Acts of Language Politeness among Adolescents at Telaga Dewa V RT 15 Bengkulu City which were studied from Sociolinguistics studies were in the form of obediance and violations of the principles of language politeness and the factors behind language politeness among adolescents in Telaga Dewa V, RT 15 Bengkulu City. . The results of research on language politeness among adolescents in Telaga Dewa V, RT 15 Bengkulu City are as follows.

\section{a. Obediance with the Principles of Language Politeness among Adolescents at Telaga Dewa V RT 15 Bengkulu City}


Obediance with the principles of language politeness among adolescents in Telaga Dewa V RT 15 Bengkulu City consists of four principles (maxims) that become rules in language politeness acts in everyday life.

\section{1) Tact Maxim}

Tact maxim is one of politeness in language, namely speech must maximize the benefits to others in speaking and losses to others in order to produce politeness when communicating and interacting (Rahardi, 2005). Examples such as those contained in the following data.

$\begin{array}{ll}\text { Social Status } & \text { : Students/teenagers/boarder } \\ \text { Time } & \text { : Afternoon, March 25, 2021, at 13.50 } \\ \text { Place } & \text { : Mrs. Ani's boarding house, Telaga Dewa V, Bengkulu City } \\ \text { Context } & \text { : A conversation took place between two teenagers who } \\ & \text { were students or boarder who were gathering to discuss the } \\ & \text { issue of books at Bu Ani's boarding house in Telaga Dewa } \\ & \text { V, RT 15, Bengkulu City. }\end{array}$

Speech form:

Debby : “Ul, kato Dara kau nyari ayuk kemaren, ndak minjam buku Manajemen Dakwah?"

(Ul, Dara said you were looking for me yesterday, wanted to borrow the Da'wah Management book, didn't you?)

Paula : "Iyo yuk, kemaren ambo ke kamar ayuk tapi kamar ayuk kunci."

(I did, yesterday I went to you room but it was locked)

Debby : "Oh iyo, maaf dek kemaren ayuk nginap di tempat kawan, dak tau kalu kau ndak minjam buku kemaren dek"

(Oh I'm sorry, I was staying at my friend's house yesterday, I didn't know if you wanted to borrow a book)

Paula : "Iyo yuk dak papo, lagi pulo kemaren tu belum ngerjo tugas yuk, luso baru ndaknyo tu, yuk."

(It's okay, besides I didn't want to do that task yet yesterday. Will do it the day after tomorrow)

Debby : "Iyo dek, kelak ambik ajo di kamar ayuk di atas yo?" (Well all right, just take it in my room above, okay?)

Paula : "Iyo yuk, Makasih yuk."

(Okay, Thank you)

(Observation, Mrs. Ani's boarding house, Telaga Dewa V/25 March 
The data above shows that the speech in the interaction between two teenagers, namely Debby (19 years old) and Widiya (18 years old) at Mrs. Ani's boarding house in Telaga Dewa V, RT 15 Bengkulu City has fulfilled one of the principles of language politeness, namely taxt maxims. This is because the speaker avoids words that are less pleasant for the interlocutor and vice versa when the interaction takes place.

\section{2) Generosity Maxim}

The maxim of generosity is a maxim or rule that makes one's own benefit as small as possible and makes the partner's profit as much as possible in speaking or interacting in order to create a polite language aspect (Rahardi, 2005). For example, as in the following data.

$\begin{array}{ll}\text { Social status } & \text { : Students/teenagers/boarder } \\ \text { Time } & \text { : Afternoon, April 13, 2021, 17.00 } \\ \text { Place } & \text { : Aliya Boarding House, Telaga Dewa V, RT 15 Bengkulu } \\ & \text { City } \\ \text { Context } & \text { : The conversation took place between two teenagers, namely } \\ & \text { Bella Chyntia (20 years) and Olin (19 years). The } \\ & \text { conversation took place when speaker 1 (Bella) asked for } \\ & \text { drinking water to speaker } 2 \text { (Olin) because she ran out of } \\ & \text { water in her room. }\end{array}$

Speech form:
Bella : "Ol, boleh minta air minum dikit buat buko kelak? Soalnyo ambo belum sempat ngisi galon." (Ol, can I have a little water for iftar later? Because I haven't had time to fill the gallon)
Olin : "Boleh Bell, itu nah ambiklah." (Yes Bell, please take it.)
Bella : "Makasih Ol" (Thanks Ol)
Olin : "Iyo,samo-samo Bell." (You're welcome Bell)

\section{(Observation, Boarding House 2 Putri/Telaga Dewa V/13 April} 2021)

In the data above, the maxim of generosity appears when speaker 1 (Bella) asks for drinking water from speaker 2 (Olin) which then speaker 2 (Olin) answers in a language that can be said to be quite polite in communicating with his interlocutor as in the second speech, that is Boleh Bell, itu nah ambiklah. (Yes Bell, please take it.)

\section{3) Approbation maxim}


From the results of observations made by the researcher, among teenagers in Telaga Dewa V, RT 15, Bengkulu City, it was found that there were several adherence to the principles of politeness in language related to the maxim of appreciation/praise in speaking or interacting as in the following data.

$\begin{array}{ll}\text { Social Status } & \text { : Students/teenagers/boarder } \\ \text { Time } & \text { : Morning, April 18, 2021, } 11.00 \text { o'clock } \\ \text { Place } & : \text { Mrs. Ani's boarding house, Telaga Dewa V, RT } 15 \\ \text { Bengkulu } & \\ \text { Context } & \text { : The conversation took place between two teenagers who live } \\ & \text { in Bu Ani's Boarding house in Telaga Dewa V, RT 15, } \\ & \text { Bengkulu City, namely Paula Putri (18 years old and } \\ & \text { Jutian Desti (18 years old). The conversation took place } \\ & \text { when speaker 1 (Paula) asked for opinions about the video } \\ & \text { editing assignment his English to speaker 2 (Desti). }\end{array}$

Speech Form :

Paula : "Des cubo tengok dulu editan samo video tugas bahasa Inggris ambo ni Des, la elok belum?"

(Des, take a look at the edits and videos of my English assignment. Is it good?)

Desti : "La elok itu Ul. Pacak nian kau ngedit Ul dan bahasa Inggris mu itu lo, Ul la lancar nian persis cak orang Inggris, hehe..."

(That's good Ul. you are very good at editing and your English is very fluent, just like the native speakers, hehe ...)

Paula : "Hehe..pacak nian kau Des, makasih lo."

(Hehe.. aww you, thanks anyway.)

2021)

(Observation, Mrs Ani's Boarding house/Telaga Dewa V/18 April

The approbation maxim in the conversation between two teenagers in data 11 above appears when speaker 1 (Paula) asks her opinion about the video she edited for an English assignment, then speaker 2 (Desti) responds that the video and language on the assignment are shown by speaker 1 (Paula) is already good.

\section{4) Modesty Maxim}

From the results of observations made among teenagers at Telaga Dewa, RT 15, Bengkulu City, the researchers found several utterances containing the modesty maxim in language politeness acts as shown in the following data.

Socia status : Students/teenagers/boarder

Time : Afternoon, April 19, 2021, at 14.30

Place : Yon boarding house, Telaga Dewa V, RT 15 Bengkulu

City 
Context $\quad$ The conversation took place between two teenagers who live in Yon's Boarding House, Telaga Dewa V, RT 15, Bengkulu City, namely Jumi Astuti (18 years) and Lia Oktaviani (18 years). The conversation took place when speaker 1 (Jumi) saw the posture of speaker 2 (Lia) which he thought was suitable for taking the police officer registration test.

Speech Form :
Jumi : "Ngapo kau idak ikut tes Polwan ajo Ya? Kan postur kek penampilan kau ko la cocok nian jadi Polwan"
(Why don't you take the Police officer test? Your posture and appearance are very suitable to be a policewoman)
Lia : "Ay pacak nian kau ni Mik, idak ambo masih banyak kekurangan dan ambo raso belum cocok kalo jadi Polwan."

(Aww come on. No, I still have a lot of shortcomings and I don't think i'm suitable to be a policewoman)

(Observation, Yon boarding house/Telaga Dewa V/19 April 2021)

\section{b. Violation of the Principles of Language Politeness among Adolescents at \\ Telaga Dewa V RT 15 Bengkulu City.}

The following is a description of the findings regarding violations of the principle of language politeness among adolescents in Telaga Dewa, RT 15, Bengkulu City in interacting or communicating.

\section{1) Violation of Tact Maxim}

Among teenagers in Telaga Dewa V, RT 15, Bengkulu City, the researcher found several speeches that violated the maxim of wisdom, for example, as in the following data.

Social status : Students/teenagers/boarder

Time : Afternoon, April 24, 2021, 13.00

Place : Yon boarding house, Telaga Dewa V, RT 15, Bengkulu

City.

Context : The conversation took place between two teenagers who live in Yon boarding house, Telaga Dewa V, RT 15, Bengkulu City, namely Yeyen (20 years) and Gadis Setia Ayu (20 years). The conversation occurred when the speaker (Yeyen) asked speaker 2 (Girl) to tidy up the motorbike that was scattered in his boarding house in a high tone.

Speech Form:

Yeyen : 'Dis! Kecekkan kek kawan-kawan kau tu, parkir motor disitu bae! Orang ko ndak lewat pulo, motor beserak cak itu, maro dirapikan dikit."

(Dis! Tell your friends, just park the motorbike 
there! Other people want to pass too, but motorbikes are scattered like that. Make it tidy.)

Gadis : "Oh iyo-iyo mbak maaf, ntar kami rapikan"

(Oh I am sorry. We'll tidy it up.)

In the speech data, it can be seen that speaker 1 (Yeyen) uttered an utterance that seems rude to speaker 2 (Girl) and reprimanded in a high tone, this clearly reduces the advantage of the interlocutor and can offend the interlocutor in interacting so that the resulting language is less polite and rough impression.

\section{2) Violation of Generosity Maxim}

In this study, the researcher found some data that contained violations of the maxim of generosity found in the conversations of teenagers in Telaga Dewa V, RT 15, Bengkulu City as well as in the following data.

$\begin{array}{ll}\text { Social status } & \text { : Students/teenagers/boarder } \\ \text { Time } & \text { : Afternoon, April 30, 2021, at 13.45 } \\ \text { Place } & \text { : Boarding House 54, Telaga Dewa V, RT } \\ \text { Bengkulu. } & \text { A conversation took place between two teenagers } \\ \text { Context } & \begin{array}{l}\text { Shella Febriani (18 years old) and Rena Regina } \\ \text { old) in front of the courtyard of boarding house }\end{array} \\ & \begin{array}{l}\text { Dewa V, RT 15, Bengkulu City. The conversa } \\ \text { place when speaker 1 (Shella) asked speaker } 2\end{array} \\ & \begin{array}{l}\text { accompany her to go to Pagar Dewa but speaker } \\ \text { did not want to and answered in a less polite man }\end{array} \\ \text { Speech form: } & \begin{array}{c}\text { Shella : "Kawani ambo ke Pagar Dewa mela Nut" } \\ \text { (Kawani saya ke Pagar Dewa mela Nut) }\end{array} \\ & \text { Rena : "Male e, ambo litak, panas!" } \\ & \text { (I don't want to, I'm tired, it's hot outside) } \\ & \text { Shella : "Yo deh, dak apo" } \\ & \text { (All right, it's okay) }\end{array}$

(Observation, Aliya Dorm/Telaga Dewa V/26 April 2021)

Violation of the maxim of generosity contained in the conversation between two teenagers in data 20 above, can be seen in the second speech made by speaker 2 (Rena), Male e, ambo litak, panas!.

\section{3) Violation of Approbation Maxim}

In a study conducted by the researcher among adolescents in Telaga Dewa V, RT 15, Bengkulu City, several violations of the maxim of approbation were found in speaking in the social community, as is the case in the following data.

Social status : Students/teenagers/boarder 


$\begin{array}{ll}\text { Time } & \text { : Afternoon, April 29, at } 14.30 \\ \text { Place } & \text { : Dua Saudara boarding house , Telaga Dewa V, RT 15, } \\ \text { Bengkulu. } & \\ \text { Context } & \text { : The conversation took place between two teenagers who } \\ & \text { live in Dua Saudara boarding house, Telaga Dewa V, RT } \\ & \text { 15, Bengkulu City, namely Elmi Sesi Nita (17 years old) } \\ & \text { and Lola Lestari (17 years old). The conversation took } \\ & \text { place when speaker 1 (Elmi) asked for an opinion about } \\ & \text { her photo on whatsap story post to speaker 2 (Lola), but } \\ & \text { speaker 2 (Lola) responded with an unpleasant response } \\ & \text { to speaker 1 (Elmi). }\end{array}$

Speech form:

$$
\begin{gathered}
\text { Elmi : "Cubo tengok snap ambo Lak, elok dak?" } \\
\text { (Take a look at my snap, isn't it good?) } \\
\text { Lola : "Percuma be elok, kalo masih pake efek filter } \\
\text { kamera hahaha" } \\
\text { (although this looks good, it is useless if you still } \\
\text { use camera filter hahaha) } \\
\text { Elmi : "Ay jadilah pulo" } \\
\text { (Nevermind) }
\end{gathered}
$$

(Observation, Dua Saudara boarding house/Telaga Dewa V/2 May

2021)

In the speech between two teenagers, namely Elmi (17 years) and Lola (17 years) in data 21 above, there is a violation of the maxim of approbation. The violation is found in the 2nd utterance spoken by speaker 2 (Lola) when speaker 1 (elmi) asks for his opinion in the conversation above, namely Percuma be elok, kalo masih pake efek filter kamera hahaha.

\section{4) Violation of Modesty Maxim}

Among teenagers in Telaga Dewa V, RT 15, Bengkulu City, there are several violations of the maxim of modesty in the aspect of language politeness when performing speech acts as shown in the following data.

$$
\begin{array}{ll}
\text { Social status } & \text { : Student/teenager/boarder and land lady } \\
\text { Time } & \text { : Afternoon, May 4, at } 14.00 \\
\text { Place } & \text { : Renafha boarding house, Telaga Dewa V, RT 15, } \\
\text { Bengkulu. } & \text { : The conversation took place between a teenager, Andika } \\
\text { Context } & \text { Kurniansyah (17 years old) and the owner of the } \\
& \text { boarding house, Mrs. Nofa at the Renafha Kosan, Telaga } \\
& \text { Dewa, RT 15, Bengkulu City. }
\end{array}
$$

Speech form:

$$
\begin{gathered}
\text { Nofa :"Dika, biso dak buat rak sepatu dari kayu bekas } \\
\text { samping tu?"” }
\end{gathered}
$$


(Dika, can you make a shoe rack from the side used wood?)

\section{Andika : "Biso lah Buk, kecik nian kalo masalah buat rak} bae."

(of course ma'am, it is a piece of cake for me.)

Nofa : "Yo udah kalo cak itu, buatkan Ibuk satu yo?"

(All right then, please make it one for me, okay?)

Andika : Okay!!

(Observation, Renafhaboarding house/Telaga Dewa V/ May 2021)

In the conversation between a teenager and the owner of a boarding house in data 24 above, there is a violation of the maxim of modesty. The violation is found in the 2nd utterance spoken by speaker 2 (Andika), Biso lah Buk, kecik nian kalo masalah buat rak bae (of course ma'am, it is a piece of cake for me). The utterances spoken by the 2nd speaker (Andika) seem arrogant or arrogant and maximize self-praise.

\section{Discussion}

Language politeness is politeness and subtlety in using language and the ethics of communicating through oral and written. The language used is full of orderly manners, manners and contains high values of respect (Budiwati, 2017). In line with the above, according to Rahardi, in acting politely, so that the message can be conveyed properly to the speech participants, the communication that occurs needs to consider the principles of language politeness (Rahardi, 2005)..

This study was conducted to determine the level of language politeness among adolescents in Telaga Dewa V, RT 15, Bengkulu City which was carried out by direct observation or observation. This can be seen in the following table.

Table 4.1: Obediance with the Principles of Language Politeness

\begin{tabular}{|c|c|c|c|c|}
\hline No & $\begin{array}{c}\text { Types of Obediance } \\
\text { with Politeness } \\
\text { Principles }\end{array}$ & Speaker & $\begin{array}{c}\text { Speaker } \\
\text { Age }\end{array}$ & Total \\
\hline \multirow[t]{7}{*}{1} & \multirow[t]{7}{*}{ Tact Maxim } & 1. Debby Syntia Monica & 19 Years & 2 Speech \\
\hline & & 2. Paula Putri & 18 Years & 2 Speech \\
\hline & & 3. Jutian Desti & 18 Years & 2 Speech \\
\hline & & 4. Ria Eka Putri & 19 Years & 1 Speech \\
\hline & & 5. Yeyen Tiara & 20 Years & 2 Speech \\
\hline & & 6. Ayuni & 20 Years & 1 Speech \\
\hline & & 7. Risky & 20 Years & 1 Speech \\
\hline 2 & Generosity Maxim & 1. Intan Oktariani & 19 Years & 1 Speech \\
\hline
\end{tabular}




\begin{tabular}{|c|c|c|c|c|}
\hline & & 2. Yesi Eka Safitri & 20 Years & 1 Speech \\
\hline & & $\begin{array}{l}\text { 3. Yoga Satya } \\
\text { Bimantara }\end{array}$ & 19 Years & 2 Speech \\
\hline & & 4. Olin & 19 Years & 1 Speech \\
\hline \multirow[t]{4}{*}{3} & \multirow[t]{4}{*}{ Approbation Maxim } & 1. Wice Yayanti & 19 Years & 1 Speech \\
\hline & & 2. Elmi Sesi Nita & 17 Years & 1 Speech \\
\hline & & 3. Jutian Desti & 18 Years & 1 Speech \\
\hline & & 4. Hilwa Ramadhani & 19 Years & 1 Speech \\
\hline \multirow[t]{3}{*}{4} & \multirow[t]{3}{*}{ Modesty Maxim } & 1. Lia Oktaviani & 19 Years & 1 Speech \\
\hline & & 2. Sindi Oktari & 20 Years & 1 Speech \\
\hline & & 3. Intan Permata Sari & 17 Years & 1 Speech \\
\hline \multicolumn{4}{|c|}{ Total } & 23 Speech \\
\hline
\end{tabular}

Table 4.2: Violations of the Principles of Language Politeness

\begin{tabular}{|c|c|c|c|c|}
\hline No & $\begin{array}{c}\text { Types of Violation of } \\
\text { the Politeness } \\
\text { Principle }\end{array}$ & Speaker & $\begin{array}{c}\text { Speaker } \\
\text { Age }\end{array}$ & $\begin{array}{l}\text { Jumlah } \\
\text { Speech }\end{array}$ \\
\hline \multirow[t]{2}{*}{1} & \multirow[t]{2}{*}{ Tact Maxim } & 1. Yeyen & 20 Years & 1 Speech \\
\hline & & 2. Widiya Aveta Sari & 18 Years & 1 Speech \\
\hline \multirow[t]{3}{*}{2} & \multirow[t]{3}{*}{ Generosity Maxim } & 1. Qeyza Salsabila & 17 Years & 1 Speech \\
\hline & & 2. Bella Chyntia & 20 Years & 1 Speech \\
\hline & & 3. Rena Regina & 19 Years & 1 Speech \\
\hline \multirow[t]{4}{*}{3} & \multirow[t]{4}{*}{ Approbation Maxim } & 1. Lola Lestari & 17 Years & 1 Speech \\
\hline & & 2. Paula Putri & 18 Years & 1 Speech \\
\hline & & 3. Dara Wiranti & 18 Years & 1 Speech \\
\hline & & 4. Gadis Setia Ayu & 20 Years & 1 Speech \\
\hline \multirow[t]{2}{*}{4} & \multirow[t]{2}{*}{ Modesty Maxim } & $\begin{array}{l}\text { 1. Andika } \\
\text { Kurniansyah }\end{array}$ & 17 Years & 1 Speech \\
\hline & & 2. Thesa & 20 Years & 1 Speech \\
\hline & & Total & & 11 Speech \\
\hline
\end{tabular}

Obediance with the principle of politeness in language among teenagers in Telaga Dewa V, RT 15, Bengkulu City can occur due to several things, such as social status and sympathy between fellow teenagers when performing speech acts in the community in everyday life. Violation of the principle of politeness in language among adolescents in Telaga Dewa V, RT 15, Bengkulu City can occur due to several factors such as environmental factors and social factors that can violate the rules of language politeness in carrying out speech acts in social society.

\section{Conclusion}


Based on the results of research that has been carried out on "Language Politeness among Adolescents in Telaga Dewa V, RT 15, Bengkulu City: Sociolinguistic Studies," the following conclusions were obtained.

1. Obediance with the principle of politeness in language among adolescents in Telaga Dewa V, RT 15, Bengkulu City, in carrying out interactions or speech acts, it was found that four maxims were obeyed consisting of 23 speeches, each of which contained maxims or language politeness rules, which is divided into 11 speeches of obedience to the tact maxim, 5 speeches of obedience to the generosity maxim, 4 speeches of obedience to the approbation maxim and 3 speeches of obedience to the modesty maxim.

2. Violations of the principle of politeness in language among adolescents in Telaga Dewa V, RT 15, Bengkulu City found as many as four maxims that were violated consisting of 11 speeches that violated the principle of language politeness in carrying out speech acts or interactions based on each maxim or linguistic rules which were divided into 2 speeches that violate the tact maxim, 3 speeches that violate the generosity maxim, 4 speeches that violate the approbation maxim and 2 speeches that violate the modesty maxim.

\section{References}

Budiwati, T. R. (2017). Kesantunan Berbahasa Mahasiswa dalam Berinteraksi dengan Dosen di Universitas Ahmad Dahlan: Analisis Pragmatik. The Urecol Proceding, (1): 559.

Chaer, A. (2010). Sosiolinguistik Pengenalan Awal. Jakarta: Rineka Cipta.

Chaer, A dan Leonie, A. (2004). Sosiolinguistik. Jakarta: Rineka Cipta

Jannah, M. (2016). Remaja dan Tugas-Tugas Perkembangannya dalam Islam. Jurnal Psikoislamedia, 1 (1): 243.

Rahardi, K. (200). Pragmatik Kesantunan Imperatif Bahasa Indonesia. Jakarta: Erlangga.

Fauziah, M. (2017). Kesantunan Sebagai Kajian Sosiolinguistik. Al-munzir, 5 (1): 454.

Malabar, S. (2015). Sosiolinguistik. Gorontalo: Ideas Publishing.

Mislikhah, S. (2014). "Kesantunan Berbahasa," Ar-Raniry: International Journal of Islamic Studies 1, 1 (2): 287.

Moleong, L.J. (2012). Metodologi Penelitian Kualitatif. Bandung: PT. Remaja Rosdakarya.

Nababan, P.W.J. (1984). Sosiolinguistik Suatu Pengantar. Jakarta: PT Gramedia Pustaka Utama. 
Ngalim, A. (2013). Sosiolinguistik Suatu Kajian Fungsional dan Analisisnya. Surakarta: PBSID FKIP UMS.

Prawira, Y.A. (2013). Keragaman Sosiolinguistik berupa Pilihan Bahasa Ragam Speech Menolak pada peserta Diklat Ditempat Kerja Kota Sukabumi Years. Jurnal Balai Diklat Keagamaan Bandung, (20): 327.

Rimbing, J dan Ruty, J.K. (2020). Tindak Tutur Anak Remaja di Kabupaten Minahasa dalam Percakapan Keluarga dan Nilai Kesantunan Berbahasa." Jurnal Membaca 5, 5 (1): 43-44.

Sugiyono. (2017). Metode Penelitian Kuantitatif, Kualitatif, dan R\&D. Bandung: Alfabeta CV.

Subyantoro. (2014). Teori Pembelajaran Bahasa. Semarang: Universitas Negeri Semarang Press. 